\title{
Evaluation of the Serological, Biochemical and Hemogram Parameters of Patients Prediagnosed with Hydatid Cyst
}

\section{Kistik Ekinokokkoz Ön Tanısı ile Başvuran Hastaların Radyolojik, Hemogram ve Biyokimyasal Analizlerinin Değerlendirilmesi}

\author{
Cemil Demir ${ }^{1}$, Songül Çetik Yıldız ${ }^{*}$ \\ ${ }^{1}$ Mardin Artuklu University, Vocational Higher School of Health Services, Department of Medical Services and \\ Techniques, Mardin, Turkey. \\ e-mail: cemildemir@ymail.com, songulcetik@gmail.com \\ ORCID: 0000-0002- 6365-0196 \\ ORCID: 0000-0002- 7855-5343 \\ *Sorumlu yazar/ Corresponding Author: Songül Çetik Yıldız \\ Gönderim Tarihi / Received: 07.12.2020 \\ Kabul Tarihi / Accepted: 03.03.2021 \\ DOI: $10.34087 /$ cbusbed.836958
}

Giriş ve Amaç: Hydatid cyst ya da echinococcosis, ülkemizde yaygın olarak görülen Echinococcus granulosus'un neden olduğu ve larval dönemin oluşturduğu zoonotik paraziter bir hastalıktır. Klinik semptomlarla bu hastalığın tanısını koymak oldukça zor olduğundan radyolojik ve serolojik yöntemlerin kullanılması gerekmektedir. Bu retrospektif çalışmada, kist hidatik ön tanısı konulan hastaların hemogram, biyokimya, radyolojik, patolojik bulguları ile epidemiyolojik verileri geriye dönük olarak incelenerek bölgemizdeki durumun belirlenip değerlendirilmesi amaçlanmıştır.

Gereç ve Yöntemler: Çalışmaya, Kamu Hastaneler Birliği Mardin Devlet Hastanesine kist hidatik ön tanısı ile çeşitli kliniklere başvuran 279'u kadın 133'ü erkek olmak üzere toplam 412 hasta dahil edilmiştir. 412 hastadan 52'ine ultrasonografi, bilgisayarlı tomografi ve radyolojik bulgular ile kist hidatik tanısı konulmuş olup 12'sinde patolojik olarak doğrulanmış toplam 64 hastanın hepsinde karaciğerde tutulumunun olduğu saptanmıştır.

Bulgular: Çalışmaya alınan 64 hastanın 38 (\%59.3)'i kadın, 26 (\%40.6)'sı erkek olup yaşları 0 ile 77 arasında değişmektedir. Hastalarda şiddetli karın ağrısı, karın şişliği, gögüs ağrısı, nefes darlığı, öksürük, ateş, bulantı, kusma en sık olarak saptanan semptomlardır. Hastaların sırasıyla; \%83.4'ü genel cerrahi, \%5.5'inin çocuk cerrahisi ve $\% 10.1$ 'inin ise diğer kliniklerine başvurduğu belirlenmiştir.

Sonuç: Biyokimyasal olarak tanı anında en sık yükselen test GGT olup, bunu ALT, AST, ALP artışı izlemiştir. Hemogram parametrelerinde RDW yüksekliği (\%29) en s1k rastlanılan bulgu olup, bunu hematokrit, hemoglobin ve MCV düşüklüğü sırayla takip etmiştir.

Anahtar kelimeler: Echinococcus granulosus, Ekinokokkozis, Epidemiyoloji, Kist hidatik, Tan1.

\section{Abstract}

Objective: Hydatid cyst or echinococcosis is a zoonotic parasitic disease caused by the larval stages of Echinococcus granulosus, which is common in our country. It is necessary to use radiological and serological methods as diagnosing this disease based on clinical symptoms is very difficult. In this retrospective study, it was aimed to determine the condition in our region by retrospectively analyzing the hemogram, biochemistry, radiological and pathological findings and the epidemiological data of the patients prediagnosed with hydatid cyst.

Materials and Methods: A total of 412 patients, 279 female and 133 male, who applied to various clinics of the Mardin State Hospital with hydatid cyst prediagnosis. 52 patients were diagnosed with hydatid cyst based on ultrasonography, computerized tomography and radiological findings, and liver involvement was detected in all 64 patients, 12 of which were pathologically verified.

Results: 38 (59.3\%) of 64 patients included in the study were female, $26(40.6 \%)$ were male and their ages ranged from 0-77. The most common symptoms were severe abdominal pain, distention, chest pain, shortness of breath, 
cough, fever, nausea and vomiting. $83.4 \%$ of the patients applied to the general surgery, $5.5 \%$ applied to the pediatric surgery and $10.1 \%$ applied to other clinics.

Conclusion: The parameter with the highest increase was GGT, followed by ALT, AST and ALP. Elevated RDW $(29 \%)$ was the most common finding in the hemogram parameters, followed by decreased MCV, hematocrit and hemoglobin.

Keywords: Diagnosis, Echinococcosis, Echinococcus granulosus, Epidemiology, Hydatid cyst.

\section{Introduction}

Hydatid cyst / hydatidosis is an infectious disease that occurs with the habitation of various tissues and organs by the parasite Echinococcus granulosus. This small parasite, which was first identified in dog intestine, has a length of 2-7 mm. Its body consists of a head (scolex) and 3-6 segments [1]. The eggs spread to the environment from the small intestine of the carnivore and infect humans and various species of animals such as goats, sheep and cattle, which are natural intermediate hosts $[2,3]$. The cyst E. granulosus, which is the cause of the disease, is mostly found in the liver (59-75\%) and lungs $(27 \%)$, but it can be found in any part of the body [4]. In previous studies, it was reported that liver hydatid cysts were the most common type in adults while pulmonary hydatid cysts were more common in the pediatric age group $[5,6]$. This disease is present as an endemic in South America, Far East, Middle East and maritime regions, and especially in countries with weak socioeconomic potential where sheep breeding is common. It is also common in our country and many of the diagnosed cases are found in the Central Anatolia region [7-10]. Screenings of individuals with healthy appearances in regions such as North Africa, Eastern Europe and the Middle East, which are endemic in terms of hydatid cyst, show that the level of prevalence ranges between $5-10 \%$ [11]. Hydatid cyst was reported to be more common in individuals who share the same environment [12].

The disease progresses asymptomatically for years due to the fact that its growth rate is slow [13]. Hydatid cyst is diagnosed with anamnesis, ultrasonography and chest radiography, other radiological screening techniques such as computerized tomography and magnetic resonance imaging, serological tests and microscopic examination when necessary [14]. Although indirect hemagglutination (IHA) tests are mostly used in the diagnosis of hydatid cyst due to easy application and time efficiency, diagnoses are also made in many regions with pathological samples taken from patients who are operated with radiological and biochemical tests. Additionally, serological, imaging, direct diagnosis and molecular methods are also used along with epidemiological data and clinical symptoms $[2,3,15]$.

In the present study, it was aimed to determine the condition in our region by retrospectively analyzing the epidemiological data of the patients prediagnosed with hydatid cyst in the state hospitals located in Mardin and the wider region between the dates January 2010 - June 2018 and to evaluate the serological, biochemistry, hemogram and radiological results.

\section{Materials and Methods}

A total of 412 patients, 279 female and 133 male, who were diagnosed with hydatid cyst in the state hospitals located in Mardin and the wider region between the dates January 2010 - June 2018, were included in the study. The ages and genders of the patients, the clinics they applied to, the serological, radiological findings and the biochemical, hemogram parameters at the time of diagnosis were evaluated retrospectively based on the data recorded in the Laboratory Data Processing System.

\section{Results and Discussion}

Hydatid cyst, which is thought to be a disease as old as mankind, is commonly observed in our country due to both social and geographical conditions. Hydatid cyst is a health problem with high morbidity and mortality in the case of late diagnosis. Prolonged hospital stay and lengthy treatment time during medical monitoring also lead to economic and mental problems. For this reason, early diagnosis and treatment of patients are of importance. Hydatid cyst is frequently observed in countries where agriculture and stockbreeding are common due to social and geographical conditions. Scolexes, which can easily infect humans through food products prepared in unsanitary conditions, most commonly settle in the liver. While liver and lung involvements are common for hydatid cysts, involvements for almost all organs are reported. Hydatid cyst disease is a serious health problem in our country, especially in Eastern and Southeastern Anatolia Region. It can produce cysts in the internal organs of humans such as liver, lungs, spleen and brain, leading to undesirable consequences [16]. Akgün et al., [17] reported that cyst formation was detected radiologically in 100 of 163 cases studied in their research, $70 \%$ of the cases had liver, $25 \%$ lung, and 5\% other organ involvement. Karadagli et al., [18] reported that it was possible to observe the disease more commonly in individuals who share the same environment and consume similar foods, considering the disease's mode of transmission. The educational backgrounds, living environments, occupations, hobbies and socioeconomic statuses of individuals in a society affect their risk of being infected by E. granulosus. The highest risk group consists of individuals who breed and butcher animals such as sheep, goats and cows in environments where infected dogs are present [12]. In the study conducted by Ozdemir [19], it was reported that $56 / 135(41.4 \%)$ of the cases were located in rural areas while $79 / 135(58.6 \%)$ of them resided in the city center. Besides being observable in all ages and genders, hydatitosis is among the diseases that are more commonly observed in adult ages. Of the 412 patients evaluated in the study, 32\% (133) were male and 68\% (279) were female (Figure 1). 


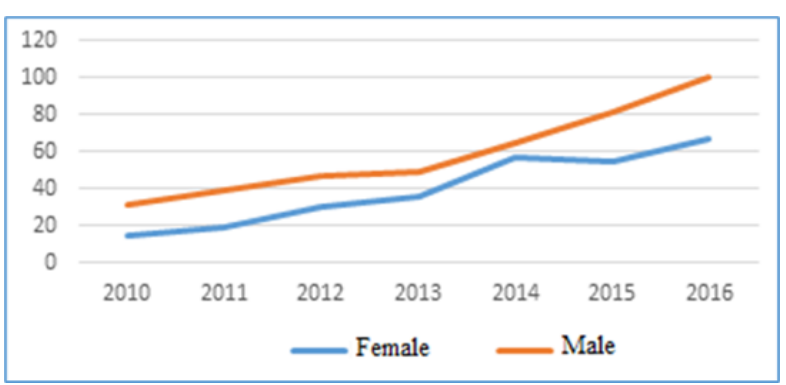

Figure 1. Distribution of the patients admitted to hospital with suspected hydatid cyst by gender.

In a similar study, $50.68 \%$ of the participants were male while $49.32 \%$ were female [20]. In previous studies, it was stated that liver hydatitosis was more common in females while pulmonary hydatitosis was more common in males $[13,21]$.

In the present study, the mean age of incidence was found to be 48 (10-77), most of which (72\%) consisted of patients over the age of 40 (Table I). In various studies conducted in Turkey, it was stated that the ages of patients with hydatid cyst ranged from 3-70 and that most of the cases were observed in the 20-44 age range $[13,21]$. In a study conducted in Uruguay, the general prevalence was determined as $5.6 \%$ and this value was calculated as $1.1 \%$ in the $4-6$ age range and $11 \%$ after the age of 60 [22]. While the mean age was determined as 25.3 in a retrospective study conducted by Isitmangil et al., [23] with 207 patients, it was determined as 27.5 in a study conducted by Dogan et al., [24] with 1055 patients. In another study conducted with 79 patients, the mean age was calculated as $38.2 ; 39.05$ for females and 37.18 for males [20]. The average age of the study group consisting of 386 females (59.9\%), 258 males (40.1\%), and a total of 644 patients, ages 7-94 was found to be 56.55 [25]. According to the studies there is no relationship between gender-age and seropositivity $[17,26]$.

Table 1. Distribution of the cases with positivity by gender and age

\begin{tabular}{|l|l|l|l|}
\hline Age & $\begin{array}{l}\text { Male (n), } \\
\text { \% }\end{array}$ & $\begin{array}{l}\text { Female (n), } \\
\%\end{array}$ & $\begin{array}{l}\text { Number } \\
\text { of } \\
\text { positivity }\end{array}$ \\
\hline $10-19$ & $1,(1.56)$ & $1,(1.56)$ & 2 \\
\hline $20-40$ & $3,(4.68)$ & $4,(6.25)$ & 7 \\
\hline $41-60$ & $14,(21.87)$ & $28,(43.75)$ & 42 \\
\hline $61-77$ & $6,(9.37)$ & $7,(10.90)$ & 13 \\
\hline Total & $24,(37.54)$ & $40,(62.46)$ & 64 \\
\hline
\end{tabular}

The distribution of the patients in the clinics are shown in Table II. $83.4 \%$ of the patients diagnosed with hydatid cysts following serological, hemogram and biochemical analyses were the patients from the general surgery clinic while $5.5 \%$ were from the pediatric surgery clinic and $10.1 \%$ were from other clinics (Table 2). In a study conducted, it was reported that the blood samples of the patients were mostly sent from general surgery $(51.5 \%)$, gastroenterology $(17.6 \%)$ and infectious diseases $(13 \%)$ clinics [25]. In the study conducted by Aytekin [20], it was stated that the patients with hydatid cyst who applied to clinics had symptoms such as cough, phlegm, side pain, shortness of breath and hemoptysis.

Table 2. Distribution of the patients admitted to hospital with suspected hydatid cyst by the clinics they applied to.

\begin{tabular}{|l|l|l|}
\hline Clinics & $\mathbf{n}$ & $\mathbf{\%}$ \\
\hline General Surgery & 344 & 83.4 \\
\hline Pediatric Surgery & 23 & 5.5 \\
\hline Internal medicine & 20 & 4.8 \\
\hline Pediatric & 10 & 2.4 \\
\hline Infection & 5 & 1.2 \\
\hline Gastroenterology & 4 & 0.9 \\
\hline Anesthesia & 4 & 0.9 \\
\hline Emergency & 1 & 0.2 \\
\hline Thoracic surgery & 1 & 0.2 \\
\hline Total & 412 & 100 \\
\hline
\end{tabular}

The absence of diagnostic specific clinical findings in hydatid cyst disease has led to the use of laboratory findings rather than clinical findings in the diagnosis of the disease. Since the specificity and sensitivity of the immunological diagnostic methods used are different and some tests do not give $100 \%$ reliable results, the development of immunological diagnostic methods with higher sensitivity and specificity is required [27]. The use of serological methods in the diagnosis of hydatid cyst is important in terms of determining the public prevalence of hydatid cyst and locating asymptomatic cysts [28,29]. Although there is no sensitivity in serological diagnosis, it was reported that high sensitivity was obtained by combining it with clinical diagnoses $[2,3,15]$. In the present study, $64(15.53 \%)$ out of 412 participating patients were tested positive for hydatid cyst, 52 $(12.62 \%)$ of which were diagnosed by means of serological, hemogram and biochemical analyses and 12 of which were diagnosed through radiology and pathology samples from surgical operations. In the study conducted by Larrieu et al., [30] it was stated that 22 $(10.2 \%)$ of the participating patients were tested serologically positive and that the disease was 20 times more common in those who shared the same environment with hydatid cyst patients. Ozdemir [19] stated that 98 out of 135 cases had positive serological examinations while the serological examinations (ELISA and IHA) of the other 37 cases were negative. The results of the indirect hemagglutination (IHA) test for serological diagnosis are shown in Table 3 . It was observed in the IHA reactive results that out of the 64 cases, the percentage of female patients was $59.2 \%$ while the percentage of male patients was $40.8 \%$. It was concluded 
that $11(\%)$ of the patient serums produced reactive results at a titration of $1: 80,13(\%)$ at $1: 160,16(\%)$ at $1: 320,11(\%)$ at $1: 640,4(\%)$ at $1: 1280$ and $9(\%)$ at $1: 2560$. According to the study with the highest number of screening results, cases of asymptomatic hydatid cyst were detected in only $192(0.44 \%)$ out of 42.734 patients in a serological and radiological screening conducted in Argentina [30]. In a study, hydatid cyst seropositivity was detected in 68 patients, $42(61.8 \%)$ female and 26 (38.2\%) male, and no statistically significant difference was found [25].

Table 3. IHA and seropositive test results for 412 patients

\begin{tabular}{|l|l|}
\hline Titrations & Number of patients \\
\hline $1 / 160$ & 45 \\
\hline $1 / 320$ & 71 \\
\hline $1 / 640$ & 52 \\
\hline $1 / 1280$ & 45 \\
\hline $1 / 2560$ & 199 \\
\hline Total & 412 \\
\hline
\end{tabular}

When the hemogram parameters of 64 patients were examined, it was determined that the most differential parameter was red blood cell distribution width (RDW) (26\%), followed by decreased hematocrit (Hct) $(21 \%)$, hemoglobin $(\mathrm{Hb})(15 \%)$ and mean corpuscular volume (MCV) (13\%). An increase in eosinophil count was observed in $13 \%$ of the patients (Figure 2).

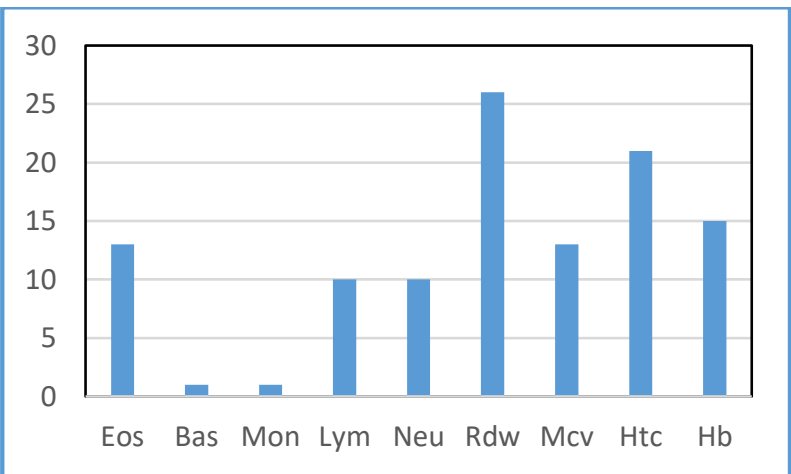

Figure 2. The distribution of the hemogram parameters of 64 patients.

In the study conducted by Sahin et al., [31] anemia $(\mathrm{Hb}<10 \mathrm{mg} / \mathrm{dl})$ was detected in 17 patients, leukocytosis (leukocyte $>10200 / \mathrm{mm}^{3}$ ) was detected in 4 patients and eosinophilia (eosinophil $>700 / \mathrm{mm}^{3}$ or $>7 \%$ ) was detected in one patient as a result of the complete blood count conducted during the diagnostic examinations of the participating patients. In a laboratory examination, Apaydin and Basaran [32] measured hemoglobin as 11.8 $\mathrm{g} / \mathrm{dl}$, leukocyte as $15.390\left(\right.$ per $\mathrm{mm}^{3}$ ) (neutrophils $88 \%$, eosinophils $0.5 \%$, lymphocytes $4.9 \%$ ), and platelet as 490.000 (per $\mathrm{mm}^{3}$ ) (26). In the study conducted by
Ghandour et al., [33] the leukocyte count was reported as $8730 / \mathrm{cm}$ (59.9\% neutrophils, $1.35 \%$ eosinophils) and hemoglobin as $15 \mathrm{~g} / \mathrm{dL}$ in the complete blood count results.

The most common result from the biochemical tests was elevated gamma-glutamyl transferase (GGT) (26\%), followed by elevated alanine aminotransferase (ALT) and aspartate aminotransferase (AST) in $13 \%$ of the patients and elevated alkaline phosphatase (ALP) in $10 \%$ of the patients (Figure 3).

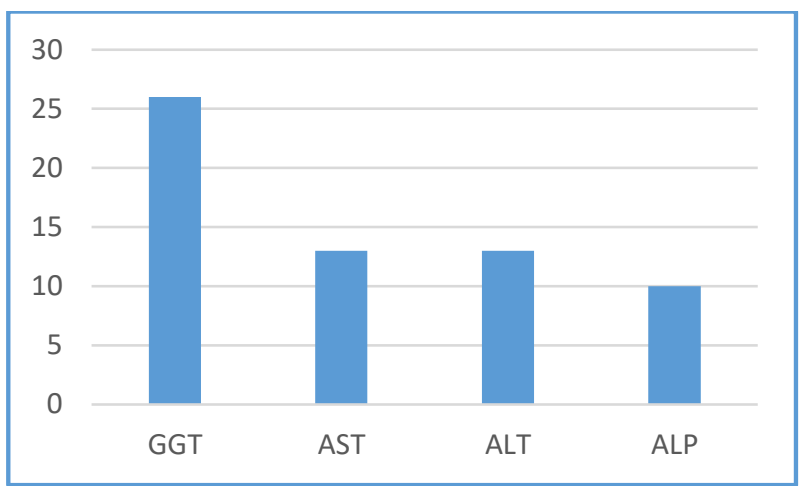

Figure 3. The distribution of the biochemical tests of 64 patients.

In the study conducted by Sahin et al., [31] the level of GGT was found to be high. Kumar et al., [34] evaluated the liver function test period and complete blood count and stated that the results were normal.

\section{Conclusion}

Hydatid cyst necessitates the development of methods with higher sensitivity due to a lack of apparent clinical symptoms and weak immune response towards larvae antigens. In conclusion, it was determined that it would be beneficial to evaluate clinical, radiological, serological and biochemical findings together in diagnosis and to inform the public with various training programs due to the fact that hydatid cyst, which is still an important public health concern in our region, can mix with the pathologies of other systems. Similarly, efforts should be made to take precautions towards protection [the main priority is to prevent the formation and transmission of the disease with the said precautions], break the life cycle of echinococcosis and raise public awareness in addition to giving importance to the treatment of the disease. Hydatid cyst should also be evaluated as a socio-economic problem and necessary solutions should be emphasized.

\section{Acknowledgements and Disclosures}

The authors report no conflicts of interest.

\section{References}

1.McManus, D.P, Characterization of echinococcus (hydatid disease) strains in Europe using DNA probes, Medecine \& Chirurgie Digestives, 1988, 17, 293-295.

2.Eckert, J, Deplazes, P, Biological epidemiological and clinical aspects of echinococcosis, a zoonosis of increasing concern, Clinical Microbiology Reviews, 2004, 17, 107-135.

3. Yılmaz, G.R, Babur, C, Ekinokokkozis tanısı, Türk Hijyen ve Deneysel Biyoloji Dergisi, 2007, 64, 35-44.

4. Yuksel, M, Demirpolat, G, Sever, A, et al., Hydatid disease involving 
some rare locations in the body: a pictorial essay, Korean Journal of Radiology, 2007, 8, 531-540.

5. Moro, P, Scantz, P.M, Ecinococcosis: a review, International Journal of Infectious Diseases, 2009, 13, 125-133.

6. Demirhan, R, Onan, B, Kiral, H, et al., Surgical treatment of giant hydatid cysts in childhood, Turkish Journal of Thoracic and Cardiovascular Surgery, 2010, 18, 121-125.

7. Sayek, I, Tirnaksiz, M.B, Dogan, R, Cystic Hydatid Disease: Curren trends in diagnosis and management, Surgery Today, 2004, 34, 987 996

8. Acarli, K, Controversies in the laparoscopic treatment of hepatic hydatid disease, Journal of the International Hepato Pancreato Biliary, 2004, 6, 213-221.

9. Altintas, N, Past to present: echinococcosis in Turkey, Acta Tropica, 2003, 85, 105-112.

10. Yazar, S, Ozkan, A.T, Hokelek, M, et al., Türkiye'de 2001-2005 yılları arasında kistik ekinokokkozis, Türkiye Parazitoloji Dergisi, 2008, 32, 208-220

11. Mandal, S, Mandal, M.D, Human cystic echinococcosis epidemiologic, zoonotic, clinical, diagnostic and therapeutic aspects, Asian Pacific Journal of Tropical Biomedicine, 2012, 5, 253-260.

12. Eilbigi, M.M, The results of radiological and serological screeningin individuals sharing the same life area with treatment of cyst hydatid patients inAfghanistan's Sibirgan Satate Hospital, Selcuk University, Institute of Health Sciences, Konya, Turkey. Specialization in Medicine, 2018, 541744

13. Baris, I, Sahin, A, Bilir, N, et al., Hidatik Kist Hastalığı ve Türkiye'deki Konumu. Türkiye Akciğer Hastalıkları Vakfı Yayını No: 1 Ankara, 1989.

14. Rajaii, M, Comparison of ELISA and IHA Diagnostic tests in the detection of human Hydatidosis in Tabriz, The International Medical Journal, 2005, 4, 14-16.

15. Kilic, S, Babur, C, Taylan, O.A, Kist hidatik ön tanılı olgularda indirek hemaglütinasyon ve ELISA yöntemleri ile alınan sonuçların karşılaştırılması, Mikrobiyoloji Bülteni, 2007, 41, 571-575.

16. Duran, E, Altay, N, Anesthesia management in hydatid cyst surgery; a retrospective analysis of 321 patients. Journal of Harran University Medical Faculty, 2019, 16(2), 280-300.

17. Akgün, S, Sayiner, H.S, Kasligil, T, The evaluation of effectiveness of indirect hemagglutination, indirect fluorescent antibody test and enzyme immunoassay in serological diagnosis of cystic Echinococcosis, Journal of Contemporary Medicine, 2018, 8(1), 1419.

18. Karadagli, E, Gürses, D, Akpınar, F, et al., Four Hydatid Cysts in One Family: Is Family Screening Necessary, Türkiye Parazitoloji Dergisi, 2015, 39, 319-322.

19. Ozdemir, G.B, Demographic investigation of medical and surgica treatments in our clinic between January 2000-December 2016 years due to cyst hydatid. Sağlık Bilimleri University, Behcet Uz Children's Diseases and Surgery Suam Pediatric Surgery, Izmir, Turkey, Specialization in Medicine, 2018, 508001.

20. Aytekin, I, Diagnosis of pulmonary hydatic cyst or pulmonary and liver hydatic cysts between August 2002 and March 2011 are investigated. Gazi University, Faculty of Medicine, Department of Thoracic Surgery, Ankara, Turkey. Specialization in Medicine, 2011 281536.

21. Gokcen, A, Kistik ekinokokkozda aşı çalışmaları, Türkiye Parazitoloji Dergisi, 2000, 24, 419- 425.

22. Kokturk, O, Akciğer Hidatik Kist Hastalığı. In: Ekim N, Ucan ES, eds. Solunum Sistemi İnfeksiyonları, Toraks Kitapları, 2001, 3, 557 604.

23. Isitmangil, T, Sebit, S, Tunc, H, et al., Clinical experience of surgica therapy in 207 patients with thoracic hydatizosis over a 12 years period, Swiss Medical Weekly, 2002, 132, 548-552.

24. Dogan, R, Yuksel, M, Cetin, G, et al., Surgical treatment of hydatid cysts of the lung; Report on 1055 patients, Thorax, 1989, 44, 192199.

25. Behçet, M, Avcıŏglu, F, Evaluation of patients with suspected cystic Echinococcosis with indirect hemagglutination method, Journal of Biotechnology and Strategic Health Research, 2020, 4(1), 26-31.

26. Karaman, Ü, Miman, Ö, Kara, M, Gıc1k, Y, Aycan, M, Atambay, M, Kars bölgesinde hidatik kist prevalansı. Türkiye Parazitoloji Dergisi, 2005, 29, 238-240
27. Sener, S, Yazar, S, Sahin, İ, Cystic echinococcosis'in indirekt flüoresan antikor testi ile tanısında kullanılan antijenlerin tanı değerlerinin araștırılması. Erciyes Üniversitesi Sağlık Bilimleri Dergisi, 2004, 13, 1-6.

28. Arienti, H.M, Guignard, S.I, Rinaldi, D.E, et al., Comparison of two serologic methods for the diagnosis of hydatidosis, Pan American Journal of Public Health, 1997, 1, 376-380.

29. Aslan, M, Yuksel, P, Polat, E, et al., The diagnostic value of Western blot method in patients with cystic echinococcosis, New Microbiologica, 2011, 34, 173-177.

30. Larrieu, E, Uchiumi, L, Salvitti, J.C, et al., Epidemiology, diagnosis, treatment and follow-up of cystic echinococcosis in asymptomatic carriers, Transactions of The Royal Society of Tropical Medicine and Hygiene, 2018, 113, 74-80.

31. Sahin, E.M, Yuksek, Y.N, Daglar, G, et al., Diagnosis and treatment of hydatid cysts: results of 120 patients, Trakya Üniversitesi Tip Fakültesi Dergisi, 2008, 25, 6-14.

32. Apaydin, T, Basaran, C, A giant cystic echinococcosis of the lung in East Turkey, Annals of Medicine and Surgery (Lond), 2018, 36, 5153

33. Ghandour, R, Nassar, G, Hejase, M.J, Renal Echinococcosis mistaken for a cystic renal tumor: A case report, Urology Case Reports, 2020, 28, 101030.

34. Kumar, N, Garg, R, Namdeo, R, Primary pelvic hydatid cyst: A rare case presenting with obstructive uropathy, International Journal of Surgery Case Reports, 2018, 53, 277-280.

http://edergi.cbu.edu.tr/ojs/index.php/cbusbed isimli yazarın CBU-SBED başlıklı eseri bu Creative Commons Alıntı-Gayriticari4.0 Uluslararas1 Lisans1 ile lisanslanmıştır. 